\title{
Debt Service of Low-Income Households in Indonesia
}

\author{
Laily Dwi Arsyianti ${ }^{1}$, Irfan Syauqi Beik ${ }^{2}$ \\ ${ }^{1} \mathrm{PhD}$ student of the International Institute of Islamic Banking and Finance, \\ International Islamic University, Malaysia \\ Email: arsyianti@gmail.com \\ ${ }^{2}$ Director, Center of Islamic Business and Economic Studies (CIBEST), \\ Bogor Agricultural University, Indonesia \\ Email: qibeiktop@gmail.com
}

\begin{abstract}
External source of fund is one way to get funds, but when it reaches 50 percent and above of disposable income, it becomes an issue. This paper attempts to elaborate determinants influencing low-income household in having 50 percent or more debt service ratio. By utilizing logistic regression approach to extract the data collected in the Greater Jakarta Indonesia, this study finds that when household head's age is 45 years old and above, having 5 dependents or more, and is a home owner, the household is the most likely to have 50 percent and above debt service. While the least likely is when household head originally from Jakarta, no worry about future domestic economy condition, and have more than USD80 income per month. Variances of education level, marital status, occupation, financing institution, charity per income are not proved statistically significantly give effect to the variance of debt service in this study.
\end{abstract}

Keywords: debt service, logistic regression, charity, low-income household

\section{Introduction}

\subsection{Background}

The need of funds is a never ending story. The deficit unit require funds to fulfil their basic needs as well as to start up a business in order to keep them survive in life. However, their access to formal financial institution is very limited, if not impossible. This situation has been seen as an opportunity by informal institution, such as payday lenders or in Indonesia, they call it as "rentenir", and in Malaysia, they call it "loanshark". The system their build is through "pop-up" demand and trust. This payday lender came to poor or low-income neighborhood as their close-friend since they offer something they need, i.e. unsecured microfinance. Unsecured means no need collateral to get the loan. However, they charged higher rate than formal institution thus left the poor in over indebted condition. This "over" occurs because the poor get another loan to repay the current debt.

Omar (2011) stated that one acquires debt due to fulfilment of basic needs. However, being indebted is not encouraged for Muslim. Muslim households and the societies at large should avoid debt-based system which discourage them being saver and investors. The households in current system obtain funds from financial and non-financial institutions to fulfil their consumption and investment (Santoso and Sukada, 2009). Meanwhile, they also provide resources to corporate and government sector. Somehow, these supply and demand activities prone to several risks that make the economy vulnerable through balance sheet approach (Allen et al, 2002). Households and sectoral balance sheet are facing the risks of maturity mismatches (where the liability due cannot be covered in short term either because of incapability to fulfill the contract commitments or the increasing risks on interest rate), currency mismatch (exposure of foreign exchange risk), capital structure problem (cash flow vulnerable due to heavy debt rather than equity in their financing), and solvency problem (where the 
total assets are inadequate to cover liabilities). Households face maturity mismatch and solvency problem risks.

Moreover, Kohsaka and Enya (2006) stated that private sector, in the sense of monetary sector, including corporates, households, and financial institutions is the fundamental reason of crisis rather than fiscal disparity in pacific region and it spread to allover other sectors. Prior 1997-1998 financial crisis hit Asia region, households in Indonesia, Korea, Malaysia and Thailand enjoy a high disposable income. As the asset price increased, the households decreased their savings and increased their debt. As reported by the Economist ${ }^{1}$, household debt in Thailand has been increasing the most, follows by Malaysia, Singapore and Indonesia in the South East Asia region. Even though, in term of debt ratio per Gross Domestic Product (GDP), Malaysia was in the first place by the end of 2012 (81 percent), followed by Thailand (68 percent), Singapore (61 percent), and Indonesia (17 percent). When the crisis hit the region, it decreased employment rate and lower disposable income. This situation to some extent increased the debt service burden and a decline in household consumption. Mainly, Benito (2007) concluded that financial stability should focus on household sector, in the extent of household debt, since this sector influence the outlook of economy into unexpected development. Debt can affect household net worth (total assets minus total external liabilities). By the risks depicted, aggregate outcomes can be affected through the outstanding debts and its distribution.

Debt can also create individual to consume more than the income. However, at some level, debt can be bad to the economy. When highly indebted persons no longer become creditworthy, lenders reduce their lending or even up to stop it, and then consumption and investment bear the consequences. If that condition continues to fall down to certain level, economy would face the increase in default, short of demand, and unbearable rate of unemployment (Cecchetti et al, 2011).

Households in Indonesia with the disposable income 1.22 up to 3.65 million rupiahs (approximately 100-300 US dollar) have the highest debt service ratio which dominated 27.97 up to 34.67 percent (vide Figure 1). In Indonesia, Muslim households whose income is above 3.6 million rupiahs are categorized as zakat payer which means that they have reached a certain level of income and obliged to pay zakat. The person who pays zakat is called muzakki. Households, whose income below that amount, objected to receive zakat since they are categorized as mustahik (recipient of zakat fund).

\footnotetext{
${ }^{1} \mathrm{http} / /$ www.economist.com/news/economic-and-financial-indicators/21588882-household-debt-asia, retrieved in August 19, 2014. 


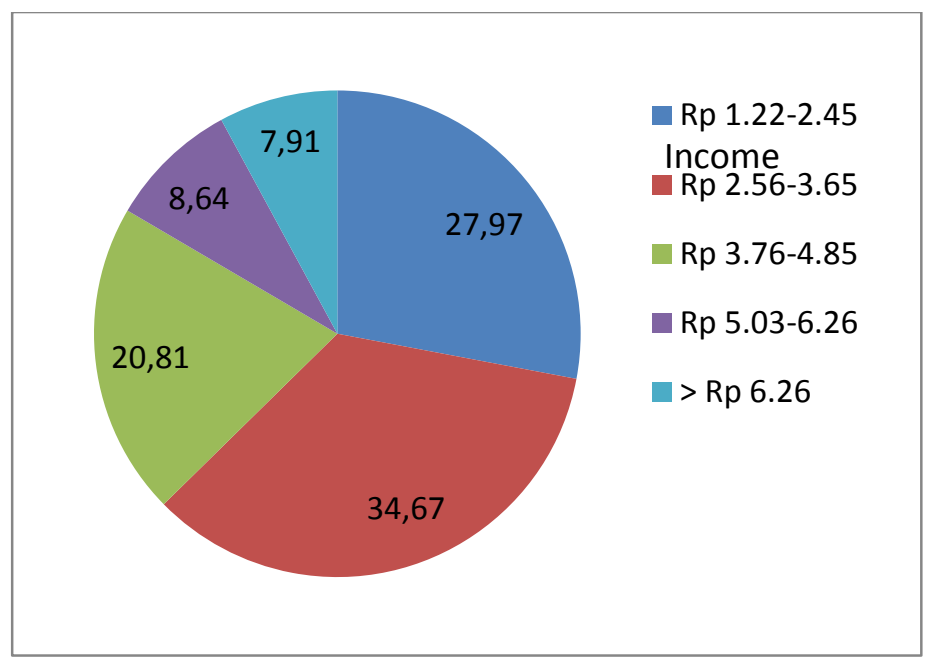

Source: Bank Indonesia (2014)

Figure 1 Debt to Service Ratio (in percentage) in Indonesia per income category of household (per September 2014) ${ }^{2}$

Liabilities in household primarily consist of loans used mostly for domestic consumption. A study done in South Africa found that original reasons of having debt consist of household consumption, consumer price index, income, and GDP (Meniago et al, 2013). Most of the loans are used for vehicle and housing purchases (Standard Chartered, 2013). It means that fulfilling their basic domestic needs still leading the way of household in having debt and ones who need this kind of debt is those who live in low-income households. The following figure shows a portion (in percent) of one household having debt per income ratio of 30 percent and above is higher in lower-income households.

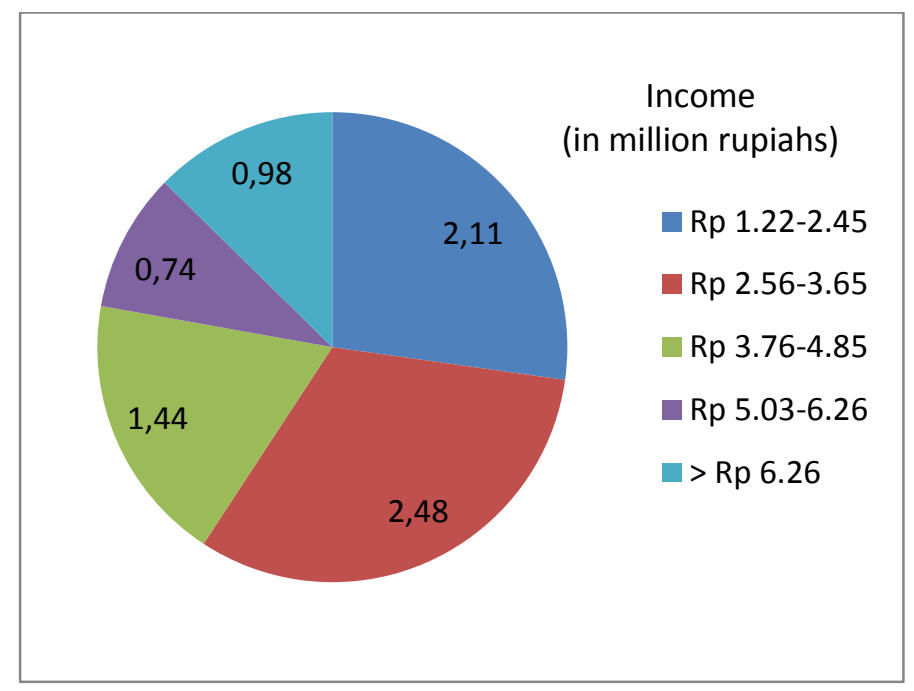

Source: Bank Indonesia (2014)

Figure 2 Debt portion (in percent) of households whose debt service ratio $>30$ percent in Indonesia per income category of household (per September 2014)

\footnotetext{
${ }^{2}$ Bank Indonesia, Financial Stability Review No.23, September 2014, page 73. 
Households finance their assets internally through relying on their net worth (accumulation of personal income) and externally through bank, non-bank and other liabilities. When households could not fulfil trough their net worth, they would find external sources to fund their needs. This would probably happen more intense for those in low-income households. Building credit is one way to build assets in low-income communities (Belsky and Retsinas, 2005). Gaberlavage and Hermanson (2001) found that even though payday lenders, pawnshops and leasing agency give an easier access to cash, they cost higher rate for credit than those institution who offer deposits and credit card. Goode (2012) reported that the most common debt was credit card, followed by instalment payments, bank/building society loans, bills and overdraft, and some take doorstep lenders and credit union. The following figure shows the growing of non-bank institution consumer financing, as it indicates an increase in nominal.

Lower-middle-income households grow along with Indonesia economy condition. This can cause a higher non-performing financing (NPL) risk to the institutions. As Santoso and Sukada (2009) reported the NPL of household debt was 3-5 percent. Since today's creditworthiness of the applicants is assessed by statistically credit records and severity of default (Belsky and Calder, 2005), the household debt for low-income household becomes an issue that should be arose. Learning from the US crises in 2008, when subprime mortgage clashed the US and entire world economy, the study of low-income households is needed.

Mostly, the study regarding debt is exposing on the households or individuals in general but none discuss on specifically in low-income households, moreover, in Indonesia. This study elaborates factors affecting the high debt service ratio among low-income households in Indonesia.

\subsection{Problem statements}

Most of people especially the low-income households whose income are less than 300 US dollar per month take debt as the way out of financial difficulties that they face. In Islam there are some consequences, for example, if we cannot repay debt, we are in difficulties to enter jannah, even those of shahid or martyrs. This group of people is in fact having the highest debt service ratio in Indonesia among other groups (Bank Indonesia, 2014).

\subsection{Objectives}

1. To identify determinants that affect debt service of low-income households in Indonesia from literatures

2. To elaborates demographic and socio-economic factors affecting the high debt service ratio among low-income households in Indonesia

\section{Literature Review}

Household behavior on debt is not much explored. However, we can draw from psychological economic literature that represents an interesting area to study household behavior of finance (Brown et al, 2005). Studies using psychological variables have been conducted and have been prove to have statistically significant implication toward debt behavior. Livingstone and Lunt (1992) study the psychological, socio and economic determinants in predicting debt. They found that socioeconomic factors play minor roles in predicting debt, while the psychological determinants show an opposite 
result. Keese (2012) has proved deeper and more recent subjective and objective measures of household debt, in the context of debt burden. Brown, et al (2005) looks into the correlation between debt and financial expectation among UK households. The result showed that households with optimistic view about their future domestic economic hold more in the amount of debt relatives with those in the pessimistic view.

Meanwhile, Pressman and Scott III (2009)'s study dealt with debt poor households who apparently come from middle class one rather than poor households. It simply happened because they rely on credit to survive and having considerable consumer credits which put them into a living standard just below the poverty threshold. Therefore, they make comparison between debt-poor households and poor households, and also between debt-poor households and middle-income households. Debt-poor households seem to have a decreasing married household-heads (compare with the poor), decreasing education level (compare with the middle-income).

Meniago, et al (2013) explored the macroeconomic factors in affecting the increasing debt in South Africa, while Santoso and Sukada (2009) have done it in Indonesia but more on financial stability impact to risk profile of households. Notwithstanding, Sahi (2013) studied the demographic-socio economic factors in influencing financial satisfaction, in which one of its indicator or proxy is amount of loan.

\section{Method}

\subsection{Source of Data}

Data was collected through questionnaires. A hundred one questionnaires have been distributed to 101 respondents. Respondents were verbally asked according to the questions provided in questionnaires. Respondents are those who come to National Board of Zakat of Indonesia (BAZNAS) main office in Jakarta. It is believed that Jakarta is a place where everybody from everywhere in Indonesia comes in. Without hesitate, only half of respondents are originally from Jakarta while others from various cities of Indonesia who came to Jakarta.

The study use cluster sampling method since the population size is unknown. When there is no complete or up-to-date lists of people, cluster sampling is appropriate to solve the problem (Cochran, 1977). Therefore, respondents were selected during their visit to BAZNAS. The research was conducted in March 2015.

\subsection{Analytical Method}

Collected data were analyzed using logistic regression method. The dependent variable is either debt per income (debt service) ratio is more than 50 percent or less. This study uses debt per income in order to explore more on the burden and economy effect on household. While the exploratory variables are education level, age, marital status, number of dependent, occupation, origin province, home ownership, financing institution, charity per income, their future expectation of domestic economy, and their income. 


\section{Level of Education}

Indonesia government has set the basic requirement for its people in order to get adequate education. This requirement is predicted to be achieved when the Indonesian people can graduate from middle high school level (SMP). Therefore, those who can achieve high school level (SMA) can go beyond the basic requirement. Knowledge shaped their behavior in managing their budget and consumption. The hypothesis is the higher the education level, the less likely households having higher debt.

Age

Plagnol (2011) found that older age results a decrease in liabilities, although their access to loan may be improved. Older people tend to have less debt attitude (Livingstone and Lunt, 1992). This can be happened because when people getting older, their children are getting older too and become adults. Adults separate from their parents and have their own financial source and not become dependent anymore. Thus, the older the age of household heads, the less likely they have debt service more than 50 percent. However, Keese (2012) found that the older report higher debt burden compare with the younger.

\section{Marital status}

Pressman and Scott III (2009) showed the result of the decreasing trend in marriage status among debt-poor household heads relative to poor households. Brown, et al (2005) also emphasized on married heads of household are found to have lower debt. In this regard, when the household situation is in a married status, the debt service is likely in lower ratio compared with those who are not married.

\section{Number of Dependent}

The lower the number of dependents can lead to the lower the need of debt in order to afford things their want (Plagnol, 2011). The same goes with Keese (2012) when he found the bigger the household size results the higher the debt-service-to-income ratio. Therefore, it is assumed that the higher the number of dependents, it is more likely to have higher debt service. However, Livingstone and Lunt (1992) found a contrary result that those who have more children are not in debt, which means bigger size family, is not necessary being in debt. The family is much more structured in budgeting and making them more salient and constant in demand.

\section{Occupation}

Respondents are segregated into employed (either employed by other or self-employed) and others (including those who unemployed, or just have unstable job, moving from one job to another within a week). Those who unemployed are more likely to have higher debt (Pressman and Scott III, 2009). The same statement also came from Keese (2012) who concludes that unemployed people tend to have pessimistic point of view regarding their future income, at that point, they anticipate for any financial problem in the future. Thus, unemployed people would tend to have more debt than those who employed. However, Bertola, et al (2006) found that for uncertain period, unemployment limit their level of borrowing. 


\section{Expectation of future domestic economy situation}

Brown, et al (2005) also found that optimistic individuals incline to have more debt than those who are pessimistic in expecting their future financial situation. Therefore, we come with the next hypothesis. They related the optimistic expectation of future financial situation with the possibility of individuals in repaying their debt. When individuals or households optimist that they can repay their debt in the future, they would have higher debt. Therefore, their result is different from Keese (2012). The study asked respondents whether they are worried or not about their future domestic economy situation.

\section{Origin}

Keese (2012) study subjective debt burden and differentiate between tenants and homeowners and dividing the origin of the respondents into East or West Germany. East Germany tenants feel less restraint while their homeowners have significantly higher subjective debt burdens. East German also show a significantly negative sign results in debt service.

\section{Home ownership}

Homeowners show a similar result with those who rent house that they have a significantly positive relationship with debt service (Keese, 2012). Possibility of having a difference variance between the two happen since homeowner is considered less constraint in debt, while tenant feel burden in paying the rent and more likely to have debt in solving the issue.

\section{Charity per income}

Charity aspect is very rarely used in study discussing debt. Mohammed (2011) developed debt and charity aspect into one model based on Al-Shaybani approach. Debt is considered as one's spending, as well as charity. However, his model put giving charity comes after paying debt since the latter is considered compulsory. This study try to test whether there is an association between the two. Charity per income is used rather than the amount of charity itself because this study wants to test the burden of charity so that it reflects more effect on household economy.

\section{Financing institution}

Unsecured debt is widely offered by informal financial institution because there is no need for collateral. This kind of debt is more accessible for low-income households. Therefore, they are more likely to get funds from informal financial institution rather than formal institutions that require a secure loan, which means collateral. In questionnaire, respondents were asked regarding their source of debt, for formal institution, includes Islamic financial institution.

\section{Income}

The greater the income may result in lower debt since they save more than those in lower income (Livingstone and Lunt, 1992). Pressman and Scott III (2009) findings also indicate that those who are in debt-poor households category (they bear more debt) are more likely to have income levels similar with poor households. In term of debt service, Keese (2012) confirms that household income has a significantly negative effect to debt service. 
Therefore, we build the variable as shown in Table 1 .

Table 1 Categorical Variables Codings

\begin{tabular}{|c|c|c|c|}
\hline & & Frequency & Parameter coding \\
\hline \multirow[t]{2}{*}{ Income } & USD80 per month and less & 47 & .000 \\
\hline & more than USD80 per month & 54 & 1.000 \\
\hline \multirow[t]{2}{*}{ Age } & younger than 45 & 51 & .000 \\
\hline & 45 and above & 50 & 1.000 \\
\hline \multirow[t]{2}{*}{ marital status } & Others & 33 & .000 \\
\hline & Married & 68 & 1.000 \\
\hline \multirow[t]{2}{*}{ Dependent } & less than 5 & 57 & .000 \\
\hline & 5 persons and above & 44 & 1.000 \\
\hline \multirow[t]{2}{*}{ Occupation } & Others & 58 & .000 \\
\hline & Employed & 43 & 1.000 \\
\hline \multirow[t]{2}{*}{ Origin } & outside Jakarta & 51 & .000 \\
\hline & Jakarta & 50 & 1.000 \\
\hline \multirow[t]{2}{*}{ home ownership } & Other & 52 & .000 \\
\hline & Owned & 49 & 1.000 \\
\hline \multirow[t]{2}{*}{ future household economic } & Worried & 81 & .000 \\
\hline & not worried & 20 & 1.000 \\
\hline \multirow[t]{2}{*}{ charity per income } & less than 2.5 percent & 82 & .000 \\
\hline & 2.5 percent and above & 19 & 1.000 \\
\hline \multirow[t]{2}{*}{ financing institution } & Informal & 87 & .000 \\
\hline & Formal & 14 & 1.000 \\
\hline \multirow[t]{2}{*}{ education level } & Other & 52 & .000 \\
\hline & graduate from high school & 49 & 1.000 \\
\hline
\end{tabular}

\section{Results and Discussion}

We utilize SPSS 17 as our tool to estimates the model. The model estimator shows that Nagelkerke R Square is 0.388 which means 38.8 percent variability of the data is explained by variables in the model. The same interpretation goes to Cox \& Snell R Square. Hosmer and Lemeshow significancy of the model test suggests us not to reject the null hypothesis which saying that the model is not lack of fit, since we are looking for the goodness-of-fit test. The result shows that the p-value is greater than 0.05 (confidence level is 95 percent), so we cannot reject the null hypothesis, which is good, and suggesting the model in good predictive value. 
Table 2 Model Summary

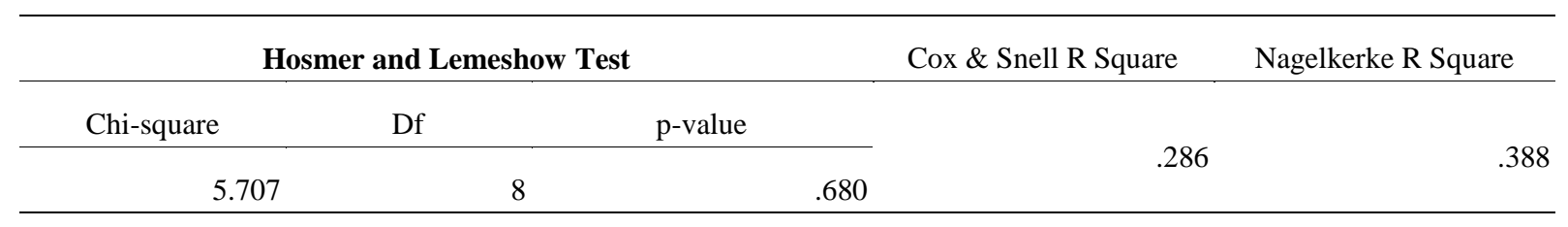

The model also classifies 75.2 percent of the cases correctly. This predicted indicator can be seen from classification table (Table 3).

Table 3 Classification Table

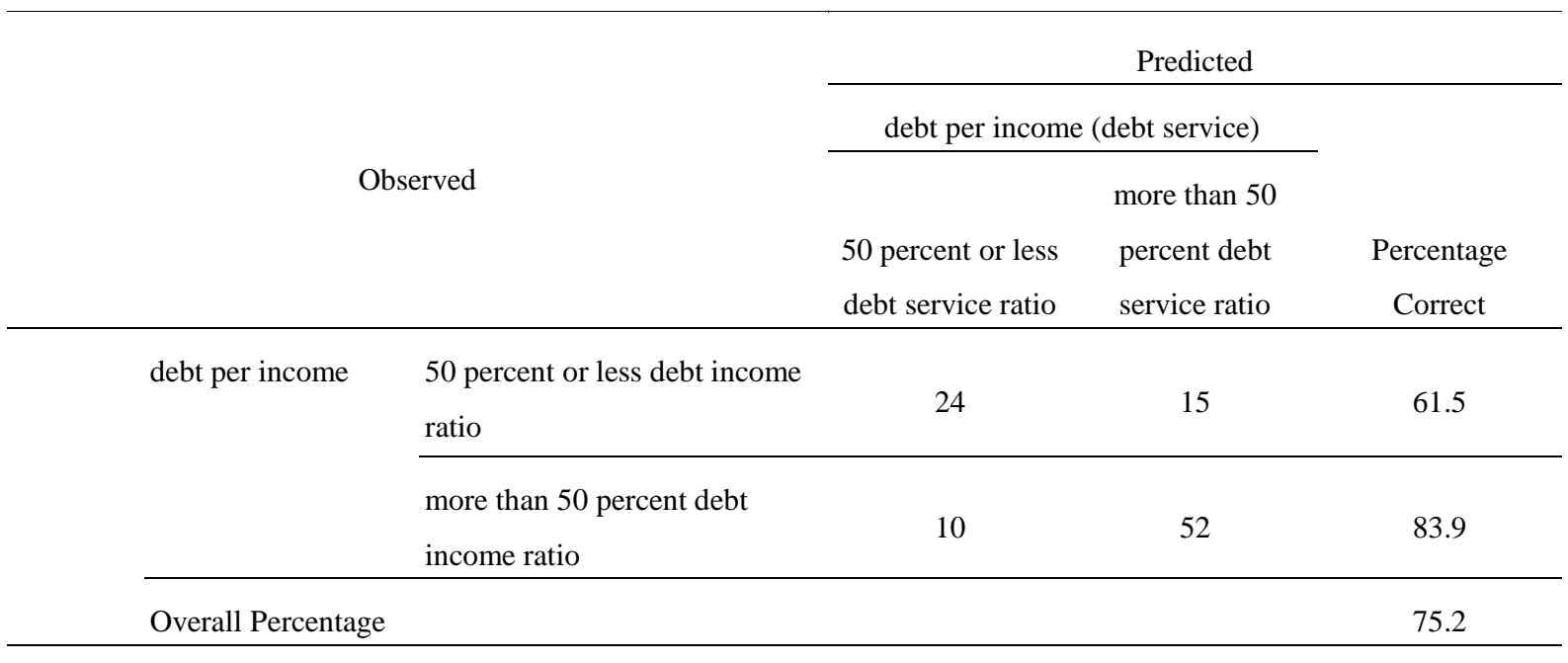

The result of variable test is shown in Table 4. There are six significant variables that explain their relationships with debt service, while the other five is not proved significantly having a relationship with and giving no effect to the variance of debt service. Those six variables are age, number of dependent, origin, home ownership, expectation of future domestic economy and income.

Age has a positive relationship with debt service. It means that those whose age is 45 years old and above are likely to have debt service 2.545 times more than those who younger. This result in line with Keese (2012) while the older burdened more in debt service. The situation happened because in Indonesia adult children are not necessarily live separate from their parents. Even though their children are already having a job, the parents still have a responsible in taking-care their children, especially for girls. The Indonesian low-income households, then, tend to taking debt even in their elderly.

\section{Table 4 Variables}

\begin{tabular}{rrrr}
\hline debt service (Y) & Coefficient & p-value & Odd ratio \\
\hline Education level (X1) & -.496 & .354 & .609 \\
\hline Age (X2) & .934 & $.092^{* * *}$ & 2.545 \\
\hline Marital status (X3) & -1.051 & .121 & .350 \\
\hline
\end{tabular}




\begin{tabular}{|c|c|c|c|}
\hline debt service (Y) & Coefficient & p-value & Odd ratio \\
\hline Number of dependent (X4) & 1.307 & $.022 * *$ & 3.696 \\
\hline Occupation (X5) & -.164 & .757 & .848 \\
\hline Origin (X6) & -1.660 & $.003 *$ & .190 \\
\hline Home ownership (X7) & 1.230 & $.029 * *$ & 3.423 \\
\hline Financing institution (X8) & .902 & .286 & 2.465 \\
\hline Charity per income (X9) & .589 & .388 & 1.801 \\
\hline Future household economy (X10) & -1.805 & $.010^{*}$ & .165 \\
\hline income (X11) & -1.507 & $.014 * *$ & .222 \\
\hline Constant & 1.761 & .039 & 5.820 \\
\hline
\end{tabular}

$*$ ) confidence level $=99 \%, * *)$ confidence level $=95 \%, * * *)$ confidence level $=90 \%$

While the elderly should less considering external source of fund in their late and should relief their responsibility on their dependents, it has been proven statistically that low-income households who have 5 dependents or more in their home incline to have more than 50 percent debt service 3.696 greater than those whose dependents are less than 5 persons. This figure implies that more dependents lead to more demand and consumptions. This situation is likely to burden low-income households and finally try to get external source of fund. They also more likely to owe money from informal financial institution such as payday loan, neighbor, relatives, hamlet society cash, and some owe money from retail shop near their house.

The result also indicates that low-income households who came from outside Jakarta struggle more to live in Jakarta so that have more debt service than those who originally stay in Jakarta from birth. They are likely to have 5.263 ( 1 divided by 0.19 ) times more than the households originally from Jakarta, which means if there is a thousand Jakartan who have debt, the non-Jakartan low-income households who have debt would be as much as 5263 .

Even though half of them are originally from Jakarta, they are not becoming homeowners. In fact, most of them are tenants. Low-income homeowners are apparently more likely to have debt 3.423 times than tenants. Seemingly, homeowners have more things to be taken care of their house. This result implies the homeowners need more fund to maintain, improve or even repair their house compare with those who just rent a house. Tenants are simply just paying the rent, while the rest are preserved by their landlady/housefather. The debt service is already taken out the house loan, so it left only consumption loans.

Pessimist low-income households who worried about their domestic economy condition are more likely to have debt than those who not worried about it. It implies that, ostensibly, pessimist households would like to take debt 6.061 ( 1 divided by 0.165 ) times since they are not confidence in their financial life in the future and worries in fulfilling their daily and their heirs' needs. This result shows a similar result with the study done by Keese (2012). 
Among low-income households who have lower income (USD80 per month or less) are more likely to have more debt than those who have income greater than USD80 per month. Findings from Livingstone and Lunt (1992), Pressman and Scott III (2009), and Keese (2012) also imply the same result. Lower income households tend to have more needs of funds, particularly from other or external sources. Their income does not enough to pay their daily life. There are 4505 households, whose income USD80 or less, in every 1000 households, whose income more than USD80, that having debt service 50 percent or more.

Variances of education level, marital status, occupation, financing institution, charity per income are not proved statistically significantly give effect to the variance of debt service. Descriptively, according to Table 1, respondents are split into two level of education which almost has a similar portion. Outwardly, the low-income household heads are not all at the basic education level, they are knowledgeable enough.

Most of the respondents are married. However, some of married household heads are on separate situation with their spouse, two of them were left by their spouse. Meanwhile, eleven respondents are already divorce because of their spouse has died.

Regarding employment status of respondents, moving from one job to another or not having a stable working hours are dominant among them. Only 43 household heads are employed and have a regular working hour daily. They are either employed by government, private corporation or self-employed such as traders and farmers.

Around 87 percent of the respondents are having debt to informal financial institutions. Nine percent of them are having debt to more than one parties. It left around only 13 percent of them who are borrowing from formal financial institution, either conventional, Islamic banks, or microfinance institutions (Baitul Maal wa Tamwil or Cooperation). Only one of them who has debt to Islamic financial institution. It means that opportunity still awaits them for Islamic financial institution promoting and offering their products.

Charity per income in this study is not proved statistically affecting the variance of debt service. Further study needs to be done in order to confirm the theory and encourage the low-income households to be involved in social sector (Oliveira, et al, 2012).

\section{Conclusion}

Low-income households in Indonesia represent 20 percent of population above poverty line in Indonesia. It is not categorized as poor neither in World Bank term nor Indonesia Bureau of Statistics but they still struggling to have a perceived standard of living, particularly in Jakarta, the capital city of Indonesia. It is statistically proved that those who came from outside Jakarta faced a more difficult situation in more likely having debt.

Regardless their origin, tenants are more preferable than buying house among low-income households in Indonesia. Moreover, homeowners are more likely to have high debt service (more than 50 percent). The old age of household heads are also more likely to have higher debt service due to their responsibility to look after their dependents. It is statistically proved that the more dependents they have, the more likely they have more than 50 percent debt service. 
If we simulate the model, the lower income earners who become pessimist and worry about future domestic economic condition are more likely to have higher debt ratio than those who have higher income and no worry about future condition. The highest figure in model, which is 99.46 percent of having more than 50 percent debt service, occurs when household head's age is 45 years old and above, having 5 dependents or more, and is a home owner. The lowest one is 3.91 percent, when household head originally from Jakarta, no worry about future domestic economy condition, and have more than USD80 income per month.

Further study needs to be done in enriching the collected data as well as embracing more regions in Indonesia so that the result would reflect deeper information. Another study in confirming the theory of relationship between charity and debt, or the behaviors related into them are also needed. This study has failed to do it may be cause of limited number of respondents.

\section{References}

Belsky ES, A Calder. 2005. Credit Matters: Building Assets in a Dual Financial Service System. Building Assets Building Credit: Creating Wealth in Low-Income Communities, pg.1-9. Washington: Brookings Institution Press.

Belsky ES, Retsinas NP. 2005. New Paths to Building Assets for the Poor. Building Assets Building Credit: Creating Wealth in Low-Income Communities, pg.1-9. Washington: Brookings Institution Press.

Brown, S, G Garino, K Taylor, SW Price. 2005. Debt and Financial Expectations: An Individual -and Household- Level Analysis. Economic Inquiry, Volume 43, Number 1, January 2005, page 100120.

Cochran, W. G. 1977. Sampling Techniques (Third Eds). Canada: John Wiley and Sons Inc.

Gaberlavage G, S Hermanson. 2001. The Alternative Financial Services Industry. Washington: AARP Public Policy Institute.

Goode, J. 2012. Brothers are doing it for themselves?: Men's experiences of getting into and getting out of debt. The Journal of Socio-Economics 41 (2012), page 327-335.

Lee, NR, M Miller. 2012. Influencing positive financial behaviors: the social marketing solution. Journal of Social Marketing. Volume 2, Issue 1, page 70-86.

Livingstone, S. M. and Lunt, P. K. 1992. Predicting personal debt and debt repayment: Psychological, social and economic determinants. Journal of Economic Psychology 13 (1992), 111-134.

Keese, M. 2012. Who feels constrained by high debt burdens? Subjective vs. Objective measures of household debt. Journal of Economic Psychology 33 (2012), 125-141.

M. Omar, M. 2011. Economic Consumption Model Revisited: Infak Model Based on Al-Shaybani's Level of Kasb. International Journal of Economic, Management and Accounting, Volume (19), 2011. Supplementary Issues, pp. 115-132.

Mann D, C Narayanan, J Caparusso, P Chandra. 2013. Asia Leverage Uncovered. Standard Chartered Global Research: Strategic Collaborative Original Universal Thematic (SCOUT).

Mazlan N. 2014. An Investigation on Household Debt in Malaysia. http://www.inceif.org/researchbulletin/investigation-household-debt-malaysia/. INCEIF. Retrieved on August 19, 2014.

Meniago, C, J Mukuddem-Petersen, MA Petersen, IP Mongale. 2013. What Causes household debt to increase in South Africa?. Economic Modelling 22 (2013), page 482-492.

OECD. 2013. Household Debt. OECD Factbook 2013: Economic, Environmental and Social Statistics. OECD Publishing. 
Oliveira, ACM, C Eckel, RTA Croson. 2012. The Stability of Social Preferences in a Low-Income Neighborhood. Southern Economic Journal 2012, 79 (1), page 15-45.

Omar, MM. 2011. Economic Consumption Model Revisited: Infaq Model Based on Al-Shaybani's Level of Al-Kasb. International Journal of Economics, Management and Accounting, Volume 19, 2011, Supplementary Issues, page 115-132.

Plagnol, A. C. 2011. Financial satisfaction over the life course: the influence of assets and liabilities. Journal of Economic Psychology Vo. 32, No. 1, pp 45-64

Pressman, S, RH Scott III. 2009. Who are the Debt Poor?. Journal of Economic Issues, Volume XLIII, Number 2, June 2009, page 423-432.

Sahi, SK. 2013. Demographic and socio-economic determinants of financial satisfaction. International Journal of Social Economics, Volume 40, Issue 2, page 127-150.

Santoso W, M Sukada. 2009. Risk Profile of Household and the Impact on Financial Stability. BIS Papers No.46, 2009, pg.58-74.

Wright, K. 2001. Generosity vs. Altruism: Philanthropy and Charity in the United States and United Kingdom. Voluntas: International Journal of Voluntary and Nonprofit Organizations, Volume 12, Number 4, December 2001, page 399-416. 